\title{
The Impact of Gender and Strategic Pre-task Planning Time on EFL Learners' Oral Performance in Terms of Accuracy
}

\author{
Ali Shafaei \\ Islamic Azad University, Maragheh Branch, Maragheh, Iran \\ Asghar Salimi \\ Maragheh University, Maragheh, Iran \\ Zahra Talebi \\ Islamic Azad University, Urmia Branch, Iran
}

\begin{abstract}
The role of planning time and gender as an interactional factor or task condition in second language development is one of the interesting issues in the realm of task-based language teaching and learning. The present study intends to investigate the effects of strategic pre-task planning and gender on EFL learners' oral task production in terms the linguistic domain of accuracy. In order to collect the data, a narrative pictorial task was employed as the means of data collection. The orally collected data was quantified and measured by means of the measure of accuracy. Then, the data was fed into the SPSS Software (Version 16) for statistical analysis. Independent Samples T-Test was employed as the statistical means of analysis. The results of the study indicated significant differences between the oral performance of the female and male learners in both planned and unplanned conditions. The results of the study carry some pedagogical implications for SLA researchers, language teachers in EFL contexts, and teacher educators.
\end{abstract}

Index Terms - task-based language teaching, task, gender, pre-task planning time, strategic planning time, accuracy

\section{INTRODUCTION}

Tasks are of great importance in recent second language acquisition literature, research, and pedagogy. This is obvious in a large number of studies and research pertaining to task-based language teaching and learning. According to Williams and Burden (1997), task is viewed as a pedagogic tool for the language teacher and a central unit for syllabus design and research. Thus, due to the importance of task, many studies over the past two decades have been carried out to investigate different aspects of it (Bygate, 2001; Robinson, 2001, 2005, 2007; Gilabert, 2005; Ortega, 1995; Skehan and Foster, 1999; Elder and Wigglesworth, 2003; Ellis, 2005; Rahimpour, 2007, 2008; Rahimpour and YaghoubiNotash, 2008; Wang, 2008; Salimi and Yousefi, 2009; Mehrang and Rahimpour, 2010; Salimi and Dadashpour, 2010; Dadashpour, 2011; Shafaei, 2012, Salimi et al, 2012; Salimi and Dadashpour, 2012a, 2012b). Planning time and gender of language learners have been the topic of research in many studies in the literature of second or foreign language research. However, their joint effect on L2 learners' oral and written task production in terms of three production elements of accuracy, fluency, and complexity is something which has rarely been explored in the field of task-based language teaching and there is a gap in the current literature on the topic. Thus, the present study was an attempt to contribute to the current literature and tried to investigate the effects of L2 learners' gender and pre-task strategic planning time on their oral task performance in terms of accuracy.

\section{LITERATURE REVIEW}

\section{A. Task-based Language Teaching and Learning (TBLT)}

According to Ellis (2003, p. 30) tasks can function as a useful device for planning a communicative curriculum, particularly in contexts where there are few opportunities for more authentic communicative experiences, for instance, many English as foreign language (EFL) learning contexts.

As Rahimpour (2008) states, task-based approaches to teaching second language concentrate on learners' ability to perform target-like tasks without any explicit teaching of grammatical rules. According to Long and Crookes (1992), these approaches involve procedural syllabuses, process syllabuses, and task-based language teaching (TBLT). The third approach, task-based language teaching (TBLT), owes its development to the dissatisfaction with the previous methods and approaches of language teaching such as audiolingual, grammar translation, etc (Salimi et al, 2012c). According to Rahimpour (2010), task-based language teaching is a response to a better understanding of a language 
learning process. Tasks, in TBLT, are considered as the units of analysis and the creation of meaning without any prior prescription of forms is emphasized in TBLT. Therefore, language learners are free to employ any strategies and forms to perform the task and achieve the task goal (Willis and Willis, 2001).

As Ellis (2005) argues task-based language teaching challenges the main approaches to language teaching in that it is based upon the fact that language learning will develop most successfully and effectively if teaching aims simply to create context and condition in which learners' natural language learning ability can be nurtured.

The various approaches to task-based language teaching (TBLT) reflect the issues that figure mainly in the current discussions of language pedagogy and SLA research. These issues are the role of meaning-based activity, the need for more learner-centered curricula, the importance of affective factors, the contribution of learner-training, and the need for some focus on form (Ellis, 2003). Task-based language teaching provides ways of addressing these various concerns and for this reason is attracting increasing attention of language teachers and researchers (Ellis, 2003).

\section{B. Definition of Task}

Crookes (1986, p. 1) argues that in neither research nor language pedagogy is there complete agreement as to what constitutes a task, making definition problematic, nor is there consistency in terms employed to describe the different devices for eliciting learner language. According to Long and Crookes (1992), task is pedagogical unit that can be used as a basis for designing language courses. By specifying what tasks are to be used course designers can create blueprints for the kinds of language use that will foster language development (Ellis, 2003, p. 27).

Different researchers and scholars have offered various definitions for the notion of task over the past two decades (Long, 1985; Prabhu, 1987; Skehan, 1996; Bygate, Skehan, and Swain, 2001; Ellis, 2003; Nunan, 2004; Tavakoli and Foster, 2008). Nunan (2004) goes on defining a task as follows:

A piece of classroom work that involves learners in comprehending, manipulating, producing or interacting in the target language while their attention is focused on mobilizing their grammatical knowledge in order to express meaning and in which the intention is to convey meaning rather than to manipulate form. The task should also have a sense of completeness, being able to stand alone as a communicative act in its own right with a beginning, middle and an end (p. 4).

\section{Planning Time in Task-based Language Teaching}

Over the past two decades, task planning has become a burgeoning area of research within task-based language teaching. As Ellis (2005, p.3) points out, planning is an indispensible part of every spoken and written language use. That is, one who wants to speak need to decide what to say and write and how to do it. Besides, Sangarun (2001, p. 6) argues that planning time is assumed to be "an important feature of language production". Comparing planned and unplanned L1 oral and written productions, Givon (1979) proposed two modes of production: the "pragmatic mode" and the "syntactic mode". On the one hand, adult L1 unplanned production, according to Givon, was comparable to the pragmatic mode in the sense that its coordination is loose, and its use of grammatical morphology is low. On the other hand, adult L1 planned production is comparable to the syntactic mode which had high subordination and high use of grammatical morphology.

Planning, in research on language production, generally involves the retrieving and organizing an utterance (Wendel, 1997). Foss and Hakes (1978) suggest that planning in language production includes formulating an idea, choosing suitable vocabulary, and organizing them "in a suitable semantic and syntactic framework" (p. 170). In language teaching, planning has been associated with interlanguage (IL) development. Interlanguage is a term first coined by Selinker (1972) and refers to the developmental language between learners' first and second languages. Corder (1981) suggests that it is a mixture language that incorporates the learner's first and second language properties, and also has its own properties. Ellis (1987) argued that planning helps the learner access the linguistic forms that have not yet been totally automated. Further, Crookes (1989) suggested that planning stretches IL and engages the processes of second language acquisition.

\section{Pre-task Planning Time and Its Types}

According to Ellis (2005) planning time is divided into two types of pre-task and within-task planning time. Pre-task planning which is the topic of this paper refers to planning that occurs before the main performance of the task (Ellis, 2005, p.3). It involves, according to Schmidt (2001), prepatory attention which contributes in performing actions with greater accuracy and speed.

In task-based language teaching, pre-task planning involves two kinds of rehearsal and strategic planning. In rehearsal, learners are given the chance to carry out the task before its main performance (Ellis, 2005, p. 3). That is, the learners' first performance of the task is considered as a practice or rehearsal for the final performance. The other type, strategic planning, refers to the learners' preparation of the content of the task they want to perform. In strategic planning, they "have access to the actual task materials" (Ellis, 2005, p.3).

\section{E. Studies Conducted on Planning Time}

Since 1980s, many SLA researchers have done several studies on the impacts of task planning and its types on language performance and language acquisition of language learners (Ochs, 1979; Crookes, 1989; Wigglesworth, 1997; 
Foster and Skehan, 1999; Yuan and Ellis, 2003; Ellis and Yuan, 2004; Kawauchi, 2005; Tavakoli and Skehan, 2005). Findings of many of these studies have indicated that planning has obvious effects on language learners' task performance in terms of complexity and fluency (Foster and Skehan 1996; Mehnert, 1998; Ortega, 1999; Foster and Skehan, 1999; Ellis and Yuan, 2004; Kawauchi, 2005) but the findings regarding language learners' accuracy have not been homogenous which is part of the focus of the present study. Crookes (1989) investigated the consequences of ten minutes pre-task planning time on the learners' performance while performing two information-gap tasks. He found that learners in planned condition produced more fluent and more complex language than the learners without planning, but the performance of learners in planned condition was not more accurate than the others. Ortega (1999) investigated the effect of strategic planning on two groups of language learners from low intermediate and advanced proficiency levels. As a result, he found that planning affected the fluency and complexity of language learners. On the contrary, planning had a beneficial effect on the lexical complexity of just the low-intermediate participants and conversely, planned narratives were more accurate in case they were produced by the advanced learners but not by the low-intermediate level speakers. Salimi and Fatollahnejad (2012) studied the effects of strategic planning and topic familiarity on Iranian intermediate EFL learners' written performance in TBLT. The results of the data analyses showed that strategic planning and topic familiarity did not have any significant effects on the learners' written task performance.

\section{F. Gender and Second Language Learning}

Gender issues in classrooms appear in a growing body of research. In many approaches to language teaching and learning, it has been delineated that females are superior to the males in language learning. The female superiority in second or foreign language learning, by most of neurolinguistic experimentations, is related to the more contribution of left hemisphere in females which is believed to be responsible for language development (Long and Crookes, 1992). Also, Oxford (1994) stated some points about the differences of male and female learners. He stated that females, specially, adults, are more dependent on the field (global) and males are more independent from the field (analytic). He also commented that females tend to be more reflective than males. Maher and Ward (2002) pointed out many implications of gender bias in classrooms and suggested that these contribute to loss of self-esteem and academic security for girls. Adolescence is also a time when the lives of boys and girls become even more sex-differentiated. Besides, Taylor (1993) strongly insists that social construction of gender is an active and ongoing process; teachers must supply materials with alternative versions of femininity-those more helpful to females in developing a sense of self and their future as women. Furthermore, Alcoff (1988) argued that gender is not a point starting, not a given, but a construct, formalizing discourse in some non-arbitrary way through a matrix of habits and practices.

Reviewing the studies carried out in the field of task-based language teaching, it was revealed that there was a gap in the current literature on the role of L2 learners' gender and pre-task planning time on their task performance in terms of three production elements of accuracy, fluency, and complexity. Therefore, the present study aimed at investigating the impact of gender and strategic pre-task planning time on EFL learners' oral performance in terms of accuracy.

\section{RESEARCH QUESTION AND HYPOTHESIS}

The above literature review yielded the following research question and research hypotheses:

$\mathbf{R Q}_{1}$ : What are the effects of gender and strategic pre-task planning time on L2 learners' oral performance in terms of accuracy?

$\mathbf{H}_{\mathbf{0}}$ : There are no significant differences between gender and strategic pre-task planning time and L2 learners' oral performance in terms of accuracy.

$\mathbf{H}_{1}$ : Female learners while performing task with strategic pre-task planning time will produce more accurate language than male ones.

\section{Methodology}

\section{A. Participants}

40 Learners of English in an intermediate level of language proficiency affiliated to Iran national Language Institute Miandoab Branch were chosen as the participants of this study. They were chosen from among the intermediate level English learners based on their performance on a pre-test which was administered in order to ensure the homogeneity of the learners participating in the study. They aged between 18-27. The participants of this study involved twenty males and twenty females. The participants were taking conversation courses for at least two years. Their first language background was Turkish and Persian. After the selection of the participants, according to the goal of the study, they were randomly divided into two groups of male and female.

\section{B. Data Collection Instrument}

In order to collect the required oral data for this study, a valid narrative pictorial task taken from the Mock or sample examinations of Cambridge University Press (2007) was employed as the data collection instrument in the study. Narrative tasks, according to Tavakoli and Skehan (2005), refer to the stories based upon a set of sequenced picture prompts which are given to language learners to elicit language performance. Attempts were made to find those picture 
prompts which were appropriate to the proficiency level of the participants in the study in terms of clarity, length, and difficulty, and were culturally familiar for the participants. Eventually, the task employed in the study was selected as the means of data collection since it is mostly suitable for the purpose of the study.

\section{Procedure}

In order to collect the data, each participant was called from the class individually to perform the narrative task. Then, they were informed of what they were expected to do. Also, the participants were told that their oral performance would be recorded while they are performing the pictorial task. Moreover, they were ensured that the recordings of their oral performance would be confidential, and that this was not a test.

The oral data for this study was collected as following. Firstly, the participants of female group were asked to perform on the narrative task with strategic pre-task planning time. They were given the pictorial task to look at it and narrate the story of the picture prompts. Then, the male learners were asked to perform on the same task. At this level (performing the narrative task with strategic pre-task planning), both male and female learners were given 10 minutes for strategic pre-task planning time. Having collected the data with strategic planning time, the participants of both male and female groups were asked to narrate the story of picture prompts without strategic pre-task planning time. That is, they were not given any time for strategic pre-task planning time before they perform on the task. It needs to be noted that the data collection without strategic pre-task planning time was conducted after an interval of two weeks. This interval was due to eliminating the learners' memorial effects. The collected oral data from the participants was transcribed, quantified, and measured by the accuracy measure employed in the study.

\section{Accuracy Measure}

To measure accuracy, percentage of error-free clauses is divided by the total number of words (Ellis, 2003).

\section{Data Analysis AND Results}

Table 1 clearly presents the means differences of accuracy of the male and female groups in narrative task with strategic pre-task planning time.

TABLE 1

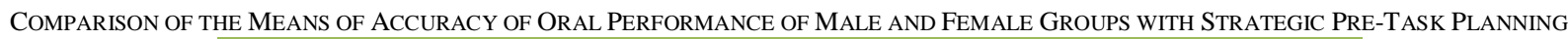

\begin{tabular}{|l|l|l|l|l|}
\hline & N & Mean & Std. Deviation & Std. Error Means \\
\hline Accuracy Planned Female & 20 & 0.51 & 0.13 & 0.03 \\
\hline Accuracy Planned Male & 20 & $\mathbf{0 . 3 4}$ & $\mathbf{0 . 0 9}$ & $\mathbf{0 . 0 2}$ \\
\hline
\end{tabular}

According to the data presented in table 1 , female learners produced more accurate $(0.51)$ language while performing narrative task with strategic pre-task planning than male learners (0.34).

Figure 1 shows the means differences of accuracy of the male and female groups in narrative task with strategic pretask planning time.

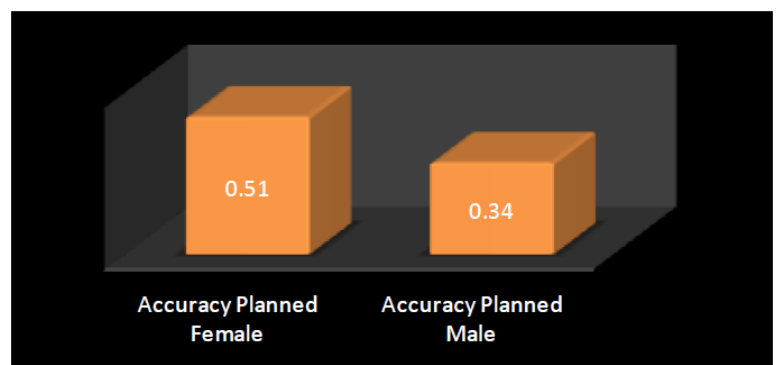

Figure 1 Comparison of the Means of Accuracy of Oral Performance of Male and Female Groups with Strategic Pre-Task Planning

Table 2 shows the results of Independent Samples T-test for the means of accuracy the male and female groups in narrative task with strategic pre-task planning time.

TABLE. 2

INDEPENDENT SAMPLES T-TEST FOR THE MEANS OF ACCURACY OF ORAL PERFORMANCE OF MALE AND FEMALE GROUPS WITH STRATEGIC PRETASK PLANNING

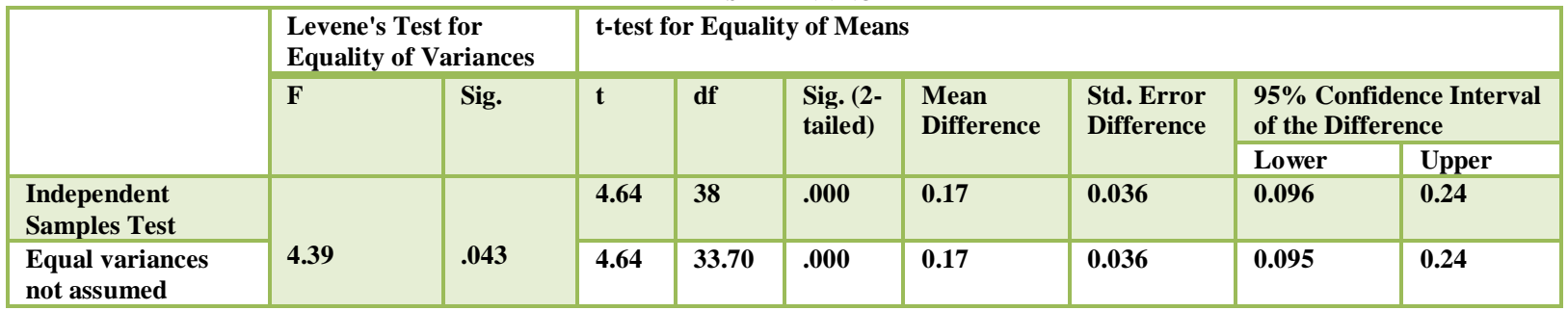


The results of statistical analysis of applying Independent Samples T-test to test the proposed hypothesis are presented in the above table. The results of SPSS at $\mathrm{df}=38$ and $\alpha=.05$, indicated that there was a significant difference between gender of the learners and strategic pre-task planning and L2 learners' accuracy of oral performance in narrative task. Therefore, the proposed null hypothesis claiming "there are no significant differences between gender and strategic pre-task planning time and L2 learners' oral performance in terms of accuracy" was rejected.

The means differences of male and female learners' oral performances in narrative task while performing the task without pre-task strategic planning are presented in the following table (table 3 ).

TABLE 3.

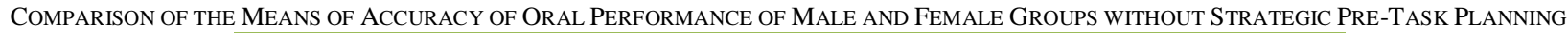

\begin{tabular}{|l|l|l|l|l|}
\hline & $\mathrm{N}$ & Mean & Std. Deviation & Std. Error Means \\
\hline Accuracy Unplanned Female & 20 & $\mathbf{0 . 4 4}$ & $\mathbf{0 . 1 1}$ & $\mathbf{0 . 0 2 4}$ \\
\hline Accuracy Unplanned Male & 20 & $\mathbf{0 . 3 5}$ & $\mathbf{0 . 1 1}$ & $\mathbf{0 . 0 2 4}$ \\
\hline
\end{tabular}

As it is clear form table 3, the learners of the female group outperformed the learners of male group in terms of accuracy of oral production in narrative task without strategic pre-task planning. Female learners produced more accurate (0.44) language while performing narrative task without strategic pre-task planning than male learners $(0.35)$.

Figure 2 clearly shows the means differences of accuracy of oral performance of the male and female groups in narrative task without strategic pre-task planning time.

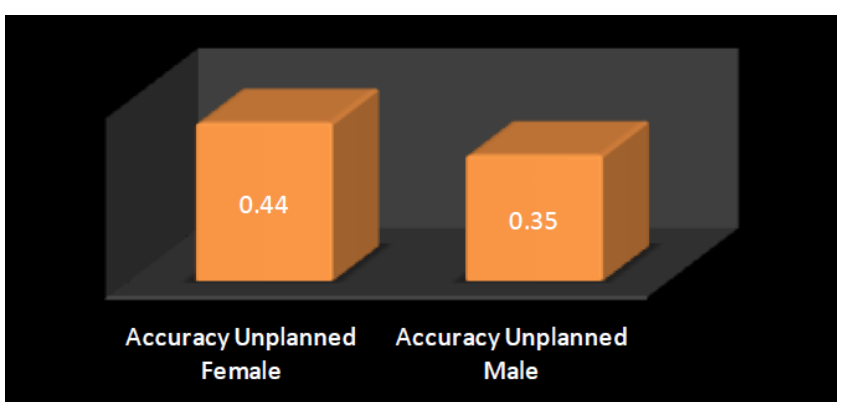

Figure 2. Comparison of the Means of Accuracy of Oral Performance of Male and Female Groups without Strategic Pre-Task Planning

Table 4 shows the results of Independent Samples T-test for the means of accuracy of oral performance of the male and female learners in narrative task without strategic pre-task planning time.

TABLE.4

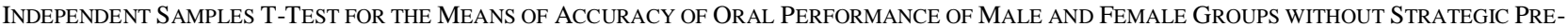
TASK PLANNING

\begin{tabular}{|c|c|c|c|c|c|c|c|c|c|}
\hline & \multicolumn{2}{|c|}{$\begin{array}{l}\text { Levene's Test } \\
\text { for Equality of } \\
\text { Variances }\end{array}$} & \multicolumn{7}{|c|}{ t-test for Equality of Means } \\
\hline & \multirow[t]{2}{*}{$\mathbf{F}$} & \multirow[t]{2}{*}{ Sig. } & \multirow[t]{2}{*}{$\mathbf{t}$} & \multirow[t]{2}{*}{ df } & \multirow[t]{2}{*}{$\begin{array}{l}\text { Sig. (2- } \\
\text { tailed) }\end{array}$} & \multirow[t]{2}{*}{$\begin{array}{l}\text { Mean } \\
\text { Difference }\end{array}$} & \multirow[t]{2}{*}{$\begin{array}{l}\text { Std. Error } \\
\text { Difference }\end{array}$} & \multicolumn{2}{|c|}{$\begin{array}{l}95 \% \text { Confidence } \\
\text { Interval of the } \\
\text { Difference }\end{array}$} \\
\hline & & & & & & & & Lower & Upper \\
\hline $\begin{array}{l}\text { Independent } \\
\text { Samples Test }\end{array}$ & \multirow[b]{2}{*}{0.033} & \multirow[b]{2}{*}{0.85} & 2.64 & 38 & 0.012 & 0.093 & 0.035 & 0.021 & 0.16 \\
\hline $\begin{array}{l}\text { Equal variances } \\
\text { not assumed }\end{array}$ & & & 2.64 & 37.99 & 0.012 & 0.093 & 0.035 & 0.021 & 0.16 \\
\hline
\end{tabular}

The results of statistical analysis of applying Independent Samples T-test to test the second hypothesis of the study are presented in table 4 . The results of SPSS at $\mathrm{df}=38$ and $\alpha=.05$, revealed that there was a significant difference between gender of the learners and strategic pre-task planning and L2 learners' accuracy of oral performance in narrative task. Therefore, female participants outperformed males. Thus, our proposed hypothesis stating that "female learners while performing task with strategic pre-task planning time will produce more accurate language than male ones" was confirmed.

\section{DISCUSSION}

Considering the impacts of gender and strategic pre-task planning time on L2 learners' oral performance in terms of accuracy in narrative task, it was found that there was a considerable difference between the learners' gender and strategic pre-task planning time and the accuracy of their oral production. That is, the female learners performing the narrative task with strategic pre-task planning time outperformed male learners in oral accuracy (Tables 2 and Figure 1). The findings of the study are in line with the findings of Foster and Skehan (1996), Rahimpour and Yaghoubi-Notash (2008). However, the findings of this study regarding accuracy of oral production are in odds with Robinson, Ting, and 
Urwin (1996), Gilabert (2005), and Mehrang and Rahimpour (2010). The production of more accurate language can be interpreted according to pragmatic and syntactic modes introduced by Givon (1989) who states that requiring learners to use greater syntactic resources and abilities will increase their grammatical accuracy. The findings of this study in terms of accuracy can be attributed to the fact stated by Skehan (1998) who argued that trade-off effects occur between different dimensions of language production due to limited attentoional resources of humans. This means that language learners are not capable of paying a balanced attention to different aspects of language simultaneously. Finally, it could be concluded that planning time, and in the case of the present study has a positive effect on L2 learners' oral production in terms of accuracy. Also, it could be concluded that females employ strategies such as planning better than male learners in their language production. The outperformance of females over males could be attributed to the precision females put on the task performance as well as their verbal language skills.

\section{PeDAGOGiCAL IMPlicAtions}

The present study carries some implications for language teachers, second language acquisition (SLA) researchers, and syllabus and task designers. The findings may contribute language teacher and, especially, syllabus designers to design instructional activities that alternate attention to all three aspect of language production (accuracy, fluency, and complexity) so that learners can develop these three elements of language production in a good balance. Furthermore, the findings of this study can contribute to methodology of task-based teaching since, as Ellis (2009) argues, planning is regarded as one of the task implementation factors which can be manipulated by providing or not providing time for learners to plan their performance, providing learners with different kinds of planning before performing a task, and giving different lengths of time for planning and the influences of planning can be viewed in language learners' language performance (Ellis, 2009). This study and its findings can have some contributions to the current SLA and task-based language teaching (TBLT) literature.

\section{REFERENCES}

[1] Alcoff, L. (1988). Cultural feminism versus post-structuralism: The identity crisis in feminist theory. Signs, 13, 405-436.

[2] Bygate, M. (2001). Effects of task repetition on the structure and control of language. In M. Bygate, P. Skehan, and M. Swain (Ed.), Researching pedagogic tasks: Second language learning, teaching and testing (pp. 23 - 48). London: Longman.

[3] Bygate, M., Skehan, P. and Swain, M. (2001). 'Introduction' in M. Bygate, P. Skehan and M. Swain (Eds.). Researching pedagogic tasks, second language learning, teaching and testing. Harlow: Longman.

[4] Corder, S. P. (1981). Error analysis and interlanguage. London: Oxford University Press.

[5] Crookes, G. (1986). Task classification: a cross-disciplinary review. Technical Report, 4, Honolulu: Center for Second Language Classroom Research, Social Science Research Institute, University of Hawaii.

[6] Crookes, G. (1989). Planning and interlanguage variation. Studies in Second Language Acquisition, 11, 367-383.

[7] Dadashpour, S. (2011). The Effects of Task Complexity on EFL Learners' Written Performance. Unpublished master's thesis, Islamic Azad University, Maragheh Branch, Maragheh, Iran.

[8] Elder, C., and Wigglesworth, G. (2003). An investigation of the effectiveness and validity of planning time in Part 2 of the IELTS Speaking Test. IELTS Research Reports, 6, 1-28.

[9] Ellis, R. (1987). Interlanguage variability in narrative discourse: Styles shifting in the use of past tense. Studies in Second Language Acquisition, 9, 1-20.

[10] Ellis, R. (2003). Task-based language learning and teaching. Oxford: Oxford University Press.

[11] Ellis, R (Ed.) (2005). Planning and task performance in a second language. Amsterdam: John Benjamins.

[12] Ellis, R. (2009). Task-based language teaching: Sorting out the misunderstandings. International Journal of Applied Linguistics 19 (3), 229-246.

[13] Ellis, R., and Yuan, F. (2004). The effects of planning on fluency, complexity, and accuracy in second language narrative writing. Studies in Second Language Acquisition, 26, 59-84.

[14] Foss, J. and D. Hakes (1978). Psycholinguistics: an introduction to the study of language. Englewood Cliffs, NJ: Prentice-Hall.

[15] Foster, P., and Skehan, P. (1996). The influence of planning and task type on second language performance. Studies in Second Language Acquisition, 9, 12-20.

[16] Foster, P., and Skehan, P. (1999). The influence of planning and focus of planning on task-based performance. Language Teaching Research, 3, 215-247.

[17] Gilabert, R. (2005). Task complexity and L2 narrative oral production. Unpublished Ph.D. dissertation. University of Barcelona, Spain.

[18] Givon, T. (1979). On understanding grammar. New York: Academic Press.

[19] Givon, T. (1989). Mind, code, and context. essays in pragmatics. Hillsdale, NJ: Erlbaum.

[20] Kawauchi, C. (2005). The effects of strategic planning on the oral narratives of learners with low and high intermediate proficiency. In R. Ellis (Ed.), Planning and task performance in a second language, pp.143-164. Amsterdam: John Benjamins.

[21] Long, M. (1985). A role for instruction in second language acquisition: task-based language teaching. In K. Hyltenstam and M. Pienemann (Eds.), Modeling and assessing second language acquisition (pp.77-99). Clevedon: Multilingual Matters.

[22] Long, M., and Crookes, G. (1992). Three approaches to task-based syllabus design. TESOL Quarterly, 26(1), 27-56.

[23] Maher, F. A., and Ward, J. V. (2002). Gender and teaching. Mahwah, J. J.: Lawrence Erlbaum Associates, Inc.

[24] Mehnert, U. (1998). The effects of different lengths of time for planning on second language performance. Studies in Second Language Acquisition, 20, 83-108. 
[25] Mehrang, F., and Rahimpour, M. (2010). The impact of task structure and planning conditions on oral performance of EFL learners. Procedia Social and Behavioral Sciences: World Conference on Educational Sciences 2010, Istanbul, Turkey.

[26] Nunan, D. (2004). Task-based language teaching. Cambridge: Cambridge University Press.

[27] Ochs, E. (1979). Planned and unplanned discourse. In Givon, T. (Ed.). Syntax and Semantics. New York: Academic Press, 51 80.

[28] Ortega, L. (1995). The effect of planning in L2 Spanish oral narratives. Studies in Second Language Acquisition, 21,108 - 148.

[29] Ortega, L. (1999). Planning and focus on form in L2 oral performance. Studies in Second Language Acquisition, 21, 109-148.

[30] Ortega, L. (2005). What do learners plan? Learner-driven attention to form during pretask planning. In Ellis, R. (Ed.) Planning and task performance in a second language. Amsterdam: John Benjamins.

[31] Oxford, R. (1994). Gender differences in second/foreign language learning styles and strategies. In Jane Sunderland (ed.) Exploring Gender: Questions and Implications for English Language Education. London: Prentice Hall.

[32] Prabhu, N. S. (1987). Second language pedagogy. Oxford: Oxford university press.

[33] Rahimpour, M. (2007). Task complexity and variation in L2 learners' oral discourse. Working Papers in Language and Linguistics, University of Queensland, 1-9.

[34] Rahimpour, M. (2008). Implementation of task-based approaches to language teaching. Pazhuhesh-e-Zabanha-ye Khareji Journal, University of Tehran, 41, 45-61.

[35] Rahimpour, M. (2010). Current trends on syllabus design in FL instruction. Procedia Social and Behavioral Sciences, 2, 166064.

[36] Rahimpour, M. and Yaghoubi-Notash, M. (2008). Examining teacher gender and student gender influence on task-prompted L2 oral variability. Issues in Applied Linguistics, 16(2), 133-150.

[37] Robinson, P. (2001). Task complexity, task difficulty, and task production: exploring interactions in a componential framework, Applied Linguistics, 22(1), 27-57.

[38] Robinson, P. (2005). Cognitive complexity and task sequencing: studies in a componential framework for second language task design. International Review of Applied Linguistics, 43, 1-32.

[39] Robinson, P. (2007). Triadic framework for TBLT: Task complexity, task difficulty, and task condition. The Journal of Asia TEFL, 195-225.

[40] Robinson, P., Chi-chien Ting, S. and Urwin, J. (1996). Three dimensions of second language task complexity. Working papers in language and linguistics, University of Queensland, 1(1), 15-30.

[41] Salimi, A. and Dadashpour, S. (2010). Task complexity and L2 learners' written performance. A paper presented at WCCES 14. Bogazici University, Istanbul, Turkey, 14-18 June.

[42] Salimi, A. and Dadashpour, S. (2012a). Task complexity and SL development: Does task complexity matter? Procedia-Social and Behavioral Sciences, 46, 726-735.

[43] Salimi, A. and Dadashpour, S. (2012b). Task Complexity and Language Production Dilemmas (Robinson's Cognition Hypothesis vs. Skehan's Trade-off Model). Procedia-Social and Behavioral Sciences, 46, 643-652.

[44] Salimi, A. and Dadashpour, S., Shafaei, and Asadollahfam, H. (2012c). Critical review of approaches to foreign language syllabus design: task-based Syllabus (a shortcut). Procedia-Social and Behavioral Sciences, 46, 828-832.

[45] Salimi, A., Shafaei, A. and Kuhi, D. (2011). The Impact of the generic features of tasks on L2 learners' written production. Procedia-Social and Behavioral Sciences, 46, 653-662.

[46] Sangarun, J. (2001). The effects of pre-task planning on foreign language performance. Doctoral thesis, University of Toronto, Canada.

[47] Schmidt, R. (2001). Attention. In Robinson, P. (Ed.), Cognition and second language instruction. Cambridge: Cambridge University Press.

[48] Selinker, L. (1972). Interlanguage. International Review of Applied Linguistics, 10, 209- 31.

[49] Shafaei, A. (2012). The effect of generic features of task on L2 learners' oral performance in EFL context. Unpublished master's thesis, Islamic Azad University, Maragheh Branch, Maragheh, Iran.

[50] Skehan, P. (1996). A framework for the implementation of task-based instruction. Applied Linguistics, 17(1), 38-62.

[51] Skehan, P. (1998). A cognitive approach to language learning. Oxford: Oxford University Press.

[52] Skehan, P. and P. Foster. (1997). Task type and task processing conditions as influences on foreign language performance. Language Teaching Research 1: 185-211.

[53] Skehan, P. and Foster, P. (1999). The influence of task structure and processing conditions on narrative retellings. Language Learning, 49(1), 93-120.

[54] Tavakoli, P., and Foster, P. (2008). Task design and second language performance: the effect of narrative type on learner output. Language Learning, 58(2), 439-473.

[55] Tavakoli, p., and Skehan, P. (2005). Strategic planning, task structure, and performance testing. In R. Ellis (Ed.), Planning and task performance in a second language (pp. 239 - 277). Amsterdam: Benjamins.

[56] Taylor, S. (1993). Transforming the text: Towards a feminist classroom practice. In L. K. Christian-Smith (Ed.), Texts of desire: Essays on fiction, femininity and schooling (pp.126-144). Washington, D.C.: The Falmer Press.

[57] Wang, Y, (2008). Influence of Planning on Students' Language Performance in Task-based Language Teaching. English language Teaching, 1 (1), 83-86.

[58] Wendel, J. N. (1997). Planning and second-language narrative production. Doctoral Thesis, Temple University.

[59] Wigglesworth, G. (1997). An investigation of planning time and proficiency level on oral test discourse. Language Testing, 14, 85-106.

[60] Williams, M., and Burden, R. L. (1997). Psychology for language teachers: a social constructivist approach. Cambridge: Cambridge University Press.

[61] Willis, D., and Willis, J. (2001). Task-based language learning. In R. Carter \& D. Nunan (Eds.), The Cambridge guide to teaching English to speakers of other languages (pp.173-179). Cambridge: Cambridge University Press. 
[62] Yuan, F., and Ellis, R. (2003). The effects of pre-task planning and on-line planning on fluency, complexity and accuracy in L2 monologic oral production. Applied Linguistics, 24 (1), 1-27.

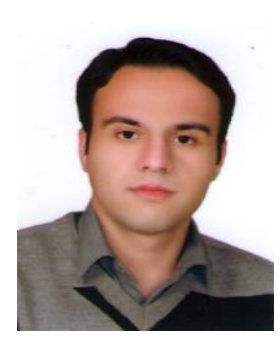

Ali Shafaei is an M.A in TEFL. He has experience of teaching in Islamic Azad University as well as Iran National Language Institution. He holds an M.A from Islamic Azad University, Maragheh Branch. His main areas of interest are task-based language teaching and genre analysis.

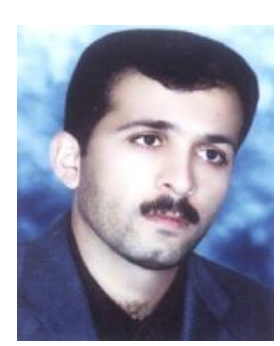

Asghar Salimi is a $\mathrm{PhD}$ in applied linguistics from University of Tabriz. He has been teaching English for over 10 years. He is currently a faculty member of Maragheh University. He has presented more than twenty papers in different national and international conferences in different countries. His main areas of interest are task-based learning and teaching, syllabus design, and Second Language Acquisition (SLA).

Zahra Talebi is an M.A in TEFL. She holds an M.A from Islamic Azad University, Urmia Branch. She is currently teaching English in Payam-e-Noor and Islamic Azad universities. 